\title{
緑地地域の特性把握と地域類型化に関する研究 \\ A STUDY ON CHARACTERISTICS AND REGIONAL CLASSIFICATION OF GREEN AREA
}

\author{
小林祐司**, 佐藤 誠治*, 姫野由香**, 広中, 聡*** \\ Yuji KOBA YASHI, Seiji SATO, Yuka HIMENO \\ and Satoshi HIRONAKA
}

\begin{abstract}
The purpose of this study is to clarify the characteristics of the green distribution area and to divide them by a classification method.

Firstly, we surveyed the land use condition, and obtained the information about the green decreasing area. Secondly, we made clear the characteristics of the green space with environmental factors. Finally, we classified the green space by the Hayashi's Quantification Theory III and the Cluster Analysis.

As a result of these analyses, these classifications agree with the real distribution of the green. And, we could understand that this analysis is an effective method to classify the green distribution.
\end{abstract}

Keywords : Landsat TM data, Green Space, Green Distribution, Regional Classification ランドサットTMデータ, 緑地, 緑地分布, 地域類型化

1. はじめに

1-1。研究の背量と目的

近年、人間の生活環境を含めた地球全体の生態系の保護と再生が 大きく取り上げられるようになってきた。戦後急激な経済・産業の 発展により、生活の豊かさと利便性は格段に向上した。しかし、発 展がもたらした陰の部分では都市の拡大による森林伐採をはじめ、 ゴミ、水質污染、大気污染等が問題になり、自然環境・生活環境の 保護・保全を如何に行っていくのか、急務の問題となっている。都 市開発・地域開発を行う際、都市全体の土地利用計画をはじめとし、 経済社会計画、更には緑地環境、生活環境に至る幅広いコントロー ル機能が必要になってくる。とりわけ、都市内部及び周辺の緑地を 如何に保全していくのかが緊急の課題となるであろう。

そこで、本論では、現在の緑地環境がどのような状況にあるの か、さらに、それらの特徽をどのように分類できるのかを検討し、 緑地の保全・活用の指針となるような指標あるいは分類の導出を目 的としている。分析の対象は福岡県北九州市である。

\section{1-2. 既往関連研究の整理と本論の位置付け}

緑地に限らず土地利用の分布特性を把握した既往研究 "がある。 その中で緑地に対象を絞り、緑地を含めた環境保全に関連する研究
としては、保全緑地を選定するための緑地の価值を評価する手法の

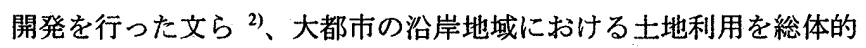
に把握するために GIS を活用して、その評価とシステムを開発し た宮崎ら ${ }^{3)}$ 、土地分級評価のために AHP 法を用い、宅地の適正を 指標化した大林ら ${ }^{4}$ の事例がある。さらに緑地分布や変化について の研究では、ポテンシャルの概念を用い、緑被率とメッシュ間距離 を指標に緑地環境評価を行った岩見ら ${ }^{5)}$ 、緑量と緑地一の近接性を 指標に、人口分布特性から緑地環境水淮を試算した青木 ${ }^{6}$ )、土地利 用変化と緑地分布の規模から緑地の減少傾向を把握した坂口ら ”、 地形的条件を考虑して、斜面緑地の残存状況を調查・分析した金子

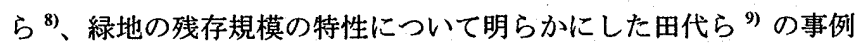
がある。

これらの研究は、特に緑地の分布状況に着目し、その特性を定量 化あるいは分類を行ったものである。しかし、分類あるいは分析の 対象となっている地点（メッシュも含む）での市街地との混合割合 等は分析の対象となっていない。本論では、緑地の類型を社会的環 境要因や、市街地と緑地との混合の状況を考慮して分類を行ってい る。つまり、市街地と緑地の関係性を把握することは、緑の利用価 值や緑との近接性といった生活・都市環境と緑地環境との現実的な 関係や問題点、課題を明らかにすることと関連している。
* 大分大学工学部建設工学科 教授. 丁博

** 大分大学工学部建設工学科 助手 $\cdot$ 修士 (工学)

*** 大分大学大学院工学研究科博士前期課程 大学院生
Prof., Dept. of Architectural Eng., Faculty of Eng., Oita Univ., Dr. Eng.

Research Assoc., Dept. of Architectural Eng., Faculty of Eng., Oita Univ., M. Eng. Graduate Student, Graduate School of Eng., Oita Univ. 


\section{2. 分析の流れとその手法}

分析は大きく 3 つに分けられる。（図 1参照)

第 1 に、士地被覆の基本的な統計量を算出した後、緑地分布に変 化がみられる地域や地点を概観する。これは 2 カ年のデータを比較 し、緑地減少率を用いて定量的に明らかにする。

第 2 に、要因を設定し、緑地分布メッシュの分類を行う。これは すなわち、緑地分布と各種要因との関係をみることに主眼がある。 ここで用いる要因では、(1)ランドサットTMデータ（以降T Mデー タ）より得られる土地被覆分類を用いた被覆指標、(2)人や空間基 盤を用いた社会的指標、(3)地形的条件を用いた地理的指標、(4)用途 地域を用いた用途地域指標、さらに(5)TM データより得られる植生 の活性度を示す NDVI と土地利用の集塊度を示す緑地環境指標を用 いる。本論ではこれらを総称して「環境要因」と呼ぶこととする。

第 3 に、数量化亚類分析、クラスター分析を用いて、緑地の特性 から類型化を行う。

本論で使用するデータ（表 1）の以下(1)から(5)は 250m メッシュ で整備した。

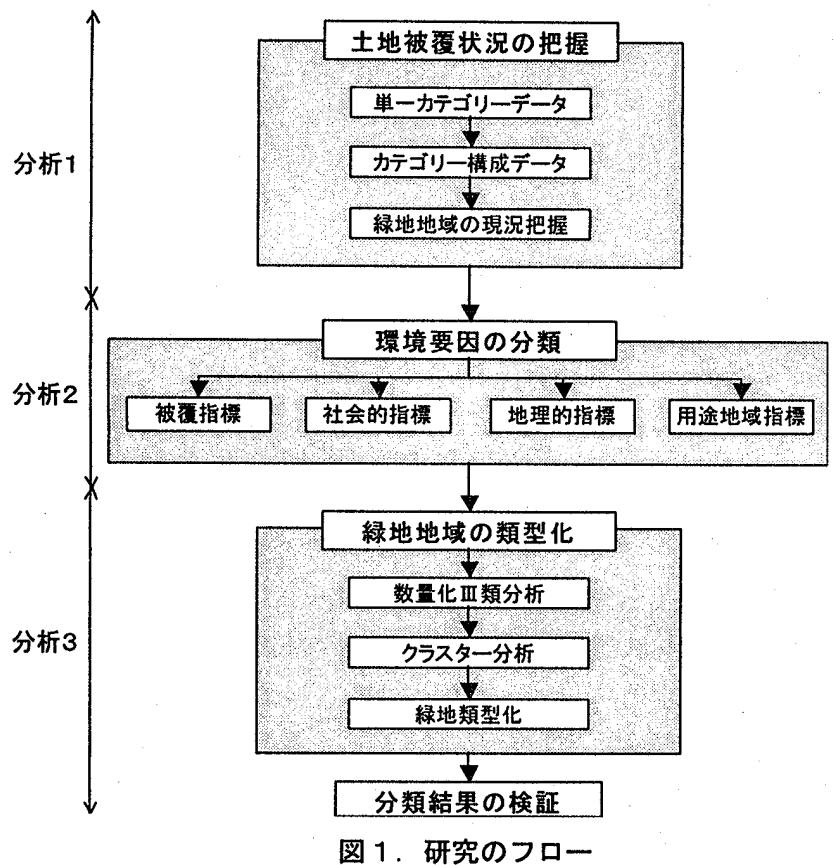

表 1. 使用するデータ

\begin{tabular}{|c|c|c|}
\hline (1) & 被覆指標 & 土地被覆分類(TMデータ \\
\hline (2) & 社会的指標 & 人口(国勢調查)之空間基盤(数值地図 $2500^{(2)}$ ) \\
\hline (3) & 地理的指標 & 標高、傾斜度 (数值地図 $50 \mathrm{~m}$ メッシュ ${ }^{(3)}$ ) \\
\hline (4) & 用途地域指標 & 用途地域 ${ }^{(4)}$ \\
\hline (5) & 緑地環境指標 & 集塊度指標 ${ }^{(5)} 、$ NDVI(TMデータ) \\
\hline
\end{tabular}

土地被覆データは、単一カテゴリーデータ、カテゴリー構成デー タの 2 つである。単一カテゴリーデータは、当該メッシュ $(250 \mathrm{~m})$ を構成する 25 個の $50 \mathrm{~m}$ メッシュの分類カテゴリ一の数が 最も多いものを当該メッシュの土地被覆として代表させた。ただし、 最大となる分類カテゴリーが 2 つ以上存在する場合は、市街地、緑 地、生産系緑地、裸地、水域の順で上位にある分類カテゴリーを代 表させている。カテゴリー構成データでは当該メッシュ $(250 \mathrm{~m})$

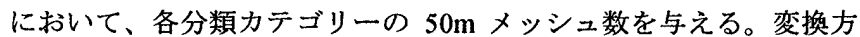

法は図 2 のおりである。

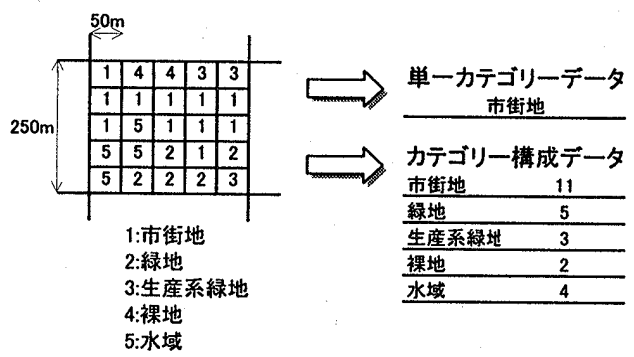

図 2. 単一カテゴリーデータとカテゴリー構成データの変換方法

\section{3. 北九州市の土地被覆状況の把握}

3ー1. 単一カテゴリーデータによる被晋状況

ここでは、本研究の対象都市である北九州市全域 $(7,653$ メッシ ュ）の土地被覆状況の把握を単一カテゴリーデータをもとに行う。 表 2 に 2 年の土地被覆状況の推移を示す。

1987 年から 1997 年にかけての経年変化をみると、市街地が $13 \%$ 増加している一方、緑地が 9\%、生産系緑地が 2\%減少している。 つまり、市街地内部もしくは周辺部に分布している緑地、生産系緑 地が市街地へ変化したと考えられる。

\section{3ー2. カテゴリー構成データによる被覆状況}

ここでは、土地被覆状況の把握をカテゴリー構成データをもとに 行う。表 3 に 2 力年の土地被覆状況の推移を示す。

市街地、緑地はメッシュ数 21 25 の区間に特に多く分布してお り、連坦した土地利用分布が同われる。一方、その他のカテゴリー はメッシュ数 1〜5 の区間に大部分が分布しており、散在した分布 であると考えられる。1987 年から 1997 年にかけて経年変化をみる と、緑地は、減少傾向にあるのは明らかである。特に高密度な緑地 散在している緑地の減少が顕著にみられる。生産系緑地、裸地の構 成メッシュは減少傾向にあるが、これは市街化に起因していると考 えられる。

\begin{tabular}{|c|c|c|c|c|}
\hline & \multicolumn{2}{|c|}{ 1987年 } & \multicolumn{2}{|c|}{ 1997年 } \\
\hline & メッッシュ数 & 割合(\%) & メッシュ数 & 割合(\%) \\
\hline 市街地 & 3,091 & 40.4 & 4,073 & 53.2 \\
\hline 緑地 & 3,969 & 51.9 & 3,296 & 43.1 \\
\hline 生産系緑地 & 413 & 5.4 & 230 & 3.0 \\
\hline 裸地 & 77 & 1.0 & 4 & 0.1 \\
\hline 水域 & 103 & 1.3 & 50 & 0.7 \\
\hline 合計 & 7,653 & 100.0 & 7,653 & 100.0 \\
\hline
\end{tabular}

表 3.土地被覆の推移（カテゴリー構成データ）

\begin{tabular}{|c|c|c|c|c|c|c|c|}
\hline \multicolumn{2}{|c|}{ 土地被覆 } & $1 \sim 5$ & $6 \sim 10$ & $11 \sim 15$ & $16 \sim 20$ & $21 \sim 25$ & $\begin{array}{c}\text { 合纾 } \\
(250 \mathrm{~m} \times \text { 吟数) }\end{array}$ \\
\hline \multirow{2}{*}{ 市街地 } & 1987 年 & 1,335 & 720 & 540 & 675 & 1,583 & 4,853 \\
\hline & 1997年 & 1,219 & 757 & 627 & 624 & 2,527 & 5,754 \\
\hline \multirow{2}{*}{ 緑地 } & 1987年 & 1,265 & 562 & 477 & 539 & 2,824 & 5,667 \\
\hline & 1997年 & 1,104 & 548 & 482 & 478 & 2,304 & 4,916 \\
\hline \multirow{2}{*}{ 生産系緑地 } & 1987年 & 1,915 & 512 & 233 & 111 & 66 & 2,837 \\
\hline & 1997年 & 1,660 & 410 & 169 & 64 & 20 & 2,323 \\
\hline \multirow{2}{*}{ 裸地 } & 1987年 & 1,397 & 137 & 41 & 16 & 5 & 1,596 \\
\hline & 1997年 & 367 & 19 & 1 & 0 & 0 & 387 \\
\hline \multirow{2}{*}{ 水域 } & 1987 年 & 424 & 38 & 25 & 16 & 17 & 520 \\
\hline & 1997年 & 491 & 39 & 11 & 12 & 4 & 557 \\
\hline
\end{tabular}

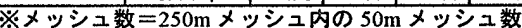

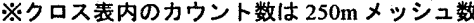

\section{3-3. 緑地地域の現況把握}

ここではカテゴリー構成データを用いて、1987 年から 1997 年に かけて緑地堿少がみられる地域を抽出し、分布傾向を概観する。変 
化の比率を表す緑地減少率により、減少した地点とその度合いを把 握する。緑地減少率は次式により求まる。

$$
\text { 緑地減少率 }=\frac{1987 \text { 年緑地数 }-1997 \text { 年緑地数 }}{1987 \text { 年緑地数 }} \times 100
$$

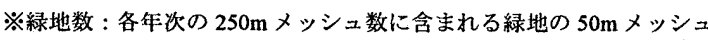

集計結果を表 4 に、緑地減少率を表した分布図を図 3 に示す。緑 地減少率が $80 \%$ 以上の地域が 4 分の 1 を占めており、また、それ らの分布は、市の南東方向に多く分布している。さらに、大きな緑 地群を取り囲むように減少率の高い地点が分布している。

\begin{tabular}{|c|c|c|}
\hline 緑地淢少率(250mメッシュ内) & \multicolumn{2}{|c|}{ メッシユ数(250mメッシュ) } \\
\hline $0 \sim 20 \%$ & 1,241 & $34.3 \%$ \\
\hline $21 \sim 40 \%$ & 731 & $20.2 \%$ \\
\hline $41 \sim 60 \%$ & 451 & $12.5 \%$ \\
\hline $61 \sim 80 \%$ & 322 & $8.9 \%$ \\
\hline $81 \sim 100 \%$ & 872 & $24.1 \%$ \\
\hline 合訫 & 3,617 & $100.0 \%$ \\
\hline
\end{tabular}

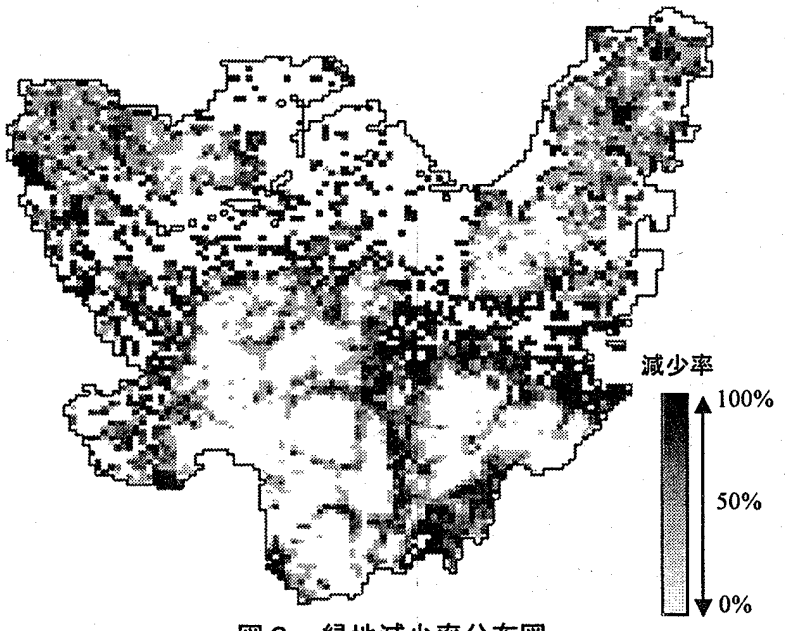

図 3，緑地減少率分布図

\section{4. 緑地地域の特性と分類}

ここでは、緑地地域の特性を把握し、以下の 4 指標から、緑地 を含むメッシュを対象として分類を行っていく。これらの指標によ り分類することで、各指標における緑地の分布傾向が把握できる。

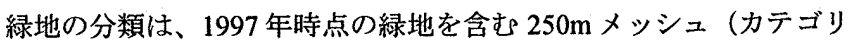
一構成データ:図 2 参照) を対象に行う。

(1)標高・傾斜度の地理的条件による指標（地理的指標）

(2)人口・交通アクセス距離等による指標（社会的指標）

(3)用途地域による指標（用途地域指標）

(4)土地被覆分類による指標（被覆指標）

\section{4-1. 地理的指標による分類と緑地分布特性}

標高、傾斜度の地理的指標に基づいて緑地を分類する。都市を 開発していく上で、その開発許容度は標高より傾斜度に大きく影響 されると考えられる。そこで、傾斜度を基準にして、標高も加味し ながら緑地の分類を行う。傾斜度を $3^{\circ}$ 未満、 $3^{\circ}$ 以上 $8^{\circ}$ 末満、

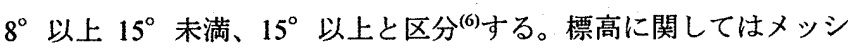

二数を考慮して、 $15 \mathrm{~m}$ 末満、 $15 \mathrm{~m}$ 以上 $100 \mathrm{~m}$ 末満、 $100 \mathrm{~m}$ 以上の 3 つに区分した。まず、表 5 から地理的な条件のもとで、緑地がどの ように分布しているかを探る。

傾斜度の小さい地点の緑地をみると、傾斜度 $3^{\circ}$ 末満の緑地、傾 斜度 $8^{\circ}$ 以上の緑地のメッシュに関しては 1,415 メッシュ、1,253 メ ッシュと傾斜度 $3^{\circ}$ 以上 $8^{\circ}$ 未満の緑地に比べ、その度数は少ない。 ほぼ平地にあたる傾斜度 $3^{\circ}$ 未満での緑地については、開発の際、 この地域に分布する緑地は最も開発行為を受けて市街化されやすい と考えられ ${ }^{(6)} 、$ 実際に他の傾斜度と比べて緑地は少ない。次に、傾 斜度 $8^{\circ}$ 以上の比較的勾配が急な地点に分布する緑地については、 コスト面から、開発行為が他の地域に比べて困難な地点であるため、 緑地の大幅な減少はないと考えられる。傾斜度 $3^{\circ}$ 以上 $8^{\circ}$ 末満の 地域は、開発行為は困難ではないが、緑地が多くなっている。この 地域は今後減少が起こる緑地を含んでいると考えられる。標高に関 しては、標高が高くなるにつれ、緑地も増えることがわかる。これ は、開発において標高が高い地域よりは、低い地域の方が当然開発 しやすいからである。

次に、表 6 のように地形的条件やメッシュ数を考慮して、緑地 を地形 $\mathrm{I} \sim$ 地形 $\mathrm{V}$ に分類した。地形 $\mathrm{I}$ は傾斜度 $3^{\circ}$ 未満で標高 $15 \mathrm{~m}$ 未満の緑地、地形 II は地形 I と同じ傾斜度で標高が $15 \mathrm{~m}$ 以上の緑 地、地形亚は傾斜度 $3^{\circ}$ 以上 $8^{\circ}$ 末満で標高 $100 \mathrm{~m}$ 末満の緑地、地 形IVは地形 III と同じ傾斜度で標高 $100 \mathrm{~m}$ 以上の緑地、地形 V は傾斜 度 $8^{\circ}$ 以上の緑地である。分布図を図 5 に示す。

\begin{tabular}{|c|c|c|c|c|c|c|}
\hline \multirow{2}{*}{ 頃斜度 } & \multicolumn{4}{|c|}{ 綠地 } & \multirow[b]{2}{*}{$\begin{array}{c}\text { 市城に占める } \\
\text { 影数(B) }\end{array}$} & \multirow{2}{*}{$\begin{array}{l}\text { (B)に対する } \\
\text { 緑地の比率 } \\
\text { (A/B) }\end{array}$} \\
\hline & 15m末渾 & $\begin{array}{l}15 \mathrm{~m} \text { 以上 } \\
100 \mathrm{~m} \text { 未満 }\end{array}$ & $100 \mathrm{mW上}$ & 合部(A) & & \\
\hline \multirow{2}{*}{$3^{\circ}$ 末満 } & 572 & 796 & 47 & 1,415 & 3,936 & \multirow{2}{*}{$35.95 \%$} \\
\hline & $11.64 \%$ & $16.19 \%$ & $0.96 \%$ & $28.78 \%$ & $51.43 \%$ & \\
\hline \multirow{2}{*}{$3^{\circ}$ 以上 $8^{\circ}$ 末満 } & 50 & 955 & 1,242 & 2,247 & 2,417 & \multirow{2}{*}{$92.97 \%$} \\
\hline & $1.02 \%$ & $19.43 \%$ & $25.26 \%$ & $45.71 \%$ & $31.58 \%$ & \\
\hline \multirow{2}{*}{$8^{\circ}$ 以上 $15^{\circ}$ 未満 } & 0 & 52. & 1,201 & 1,253 & 1,299 & \multirow{2}{*}{$96.46 \%$} \\
\hline & $0.00 \%$ & $1.06 \%$ & $24.43 \%$ & $25.49 \%$ & $16.97 \%$ & \\
\hline \multirow{2}{*}{$15^{\circ}$ 以上 } & 0 & 0 & 1 & 1 & 1 & \multirow{2}{*}{$100.00 \%$} \\
\hline & $0.00 \%$ & $0.00 \%$ & $0.02 \%$ & $0.02 \%$ & $0.01 \%$ & \\
\hline \multirow{2}{*}{ 合㖕 } & 622 & 1,803 & 2,491 & $4,916^{(0)}$ & 7,653 & \multirow{2}{*}{$64.24 \%$} \\
\hline & $12.65 \%$ & $36.68 \%$ & $50.67 \%$ & $100 \%$ & $100 \%$ & \\
\hline
\end{tabular}

※度数はいずれも $250 \mathrm{~m}$ メッシュ数

$(* 1): 1997$ 年の緑地の $250 \mathrm{~m}$ メッシュ数

\begin{tabular}{|c|c|c|c|}
\hline 傾斜度 & $15 \mathrm{~m}$ 未満 & \begin{tabular}{|l|}
$15 \mathrm{~m}$ 以上 \\
$100 \mathrm{~m}$ 末満
\end{tabular} & $100 \mathrm{~m}$ 以上 \\
\hline $3^{\circ}$ 未滿 & 地形 I & \multicolumn{2}{|c|}{ 地形 II } \\
\hline $3^{\circ}$ 以上 $8^{\circ}$ 末満 & \multicolumn{2}{|c|}{ 地形 III } & 地形 IV \\
\hline $8^{\circ}$ 以上 & \multicolumn{3}{|c|}{ 地形 V } \\
\hline
\end{tabular}

\section{4-2. 社会的指標による分類と緑地分布特性}

社会的指標として九州自動車道インターチェンジ(九州道 IC)、都 市高速インターチェンジ（都市高速 IC）、国道の交通施設への距 離（直線距離）、小中学校、高校、大学、公園、鉄道駅への距離 (直線距離) 、人口密度の 9 指標を用いて、緑地の分類を行う。

社会的指標 (9 指標) による主成分分析を行い、分類軸として累 積寄与率が約 7 割となる第 2 主成分まで採用した。表 7 に分析に用 いた指標と分析結果を、図 4 に成分プロット図を示す。表 7 をみる と第 1 主成分（第 1 軸）では都市高速 IC、小中学校、高校、大学、 公園、駅、人口密度の因子負荷量が高く、第 2 主成分（第 2 軸）で 
は九州道 IC、国道の因子負荷量が高くなっていることがわかる。 次に、得られた軸の解釈を行っていく。成分プロット図の人口 密度をみると、第 1 軸と第 2 軸にかなり影響している。その他の学 校 (小中学校・高・大学) 、都市高速 IC、公園、鉄道駅も第 1 軸 に影響しており、これらの社会的指標情都市機能や人口密度に関係 している。つまり、第 1 軸は都市機能・人口集積性を表わす軸と考 えられる。第 1 主成分の值が小さいほど都市機能・人口集積性は高 くなる。次に第 2 軸についてみると、ここでは九州道 IC、国道が 主に影響している。加えて鉄道駅も第 2 軸に近い值で影響している ことがわかる。このことから第 2 軸は既存の交通施設の分布状況、 つまり交通施設開発度を表わす軸と考えられる。第 2 主成分の值が 小さいほど交通施設開発度は高くなる。

\section{表 7. 主成分分析結果（因子負荷量）}

\begin{tabular}{c|r|r}
\hline 変亶 & 第1主成分 & 第2主成分 \\
\hline \hline 九州道IC & -0.121 & 0.467 \\
\hline 都市高速IC & 0.827 & 0.090 \\
\hline 国道 & 0.275 & 0.889 \\
\hline 小中学校 & 0.728 & 0.322 \\
\hline 高校 & 0.939 & 0.151 \\
\hline 大学 & 0.801 & 0.021 \\
\hline 公園 & 0.899 & 0.050 \\
\hline 鉄道駅 & 0.334 & 0.861 \\
\hline 人口密度 & -0.468 & -0.379 \\
\hline \hline 固有值 & 3.967 & 2.031 \\
\hline 寄与率(\%) & 44.075 & 22.568 \\
\hline 累積寄与率(\%) & 44.075 & 66.644 \\
\hline
\end{tabular}

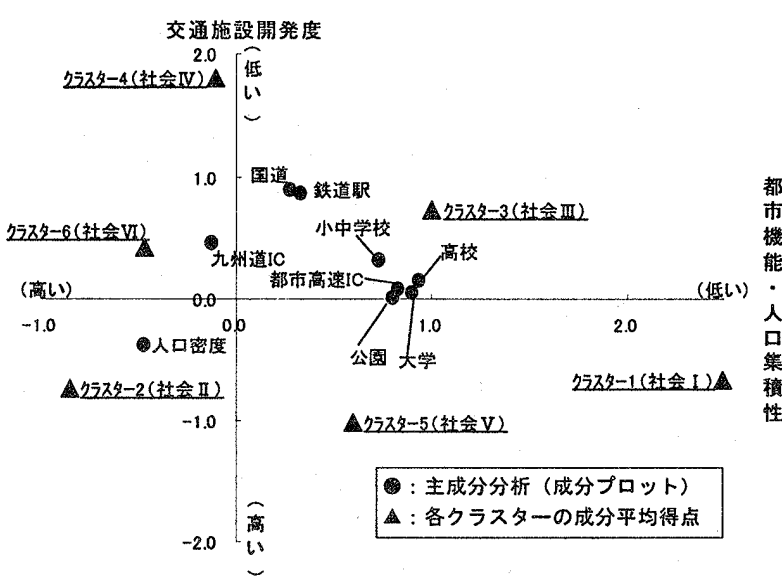

図 4、成分プロット図

次に、主成分分析から得られた都市機能・人口集積と交通施設 開発度の 2 成分からクラスター分析 (最短距離法) を行い、社会的 指標による緑地の分類を行った。図 4 中に 6 クラスターの第 $1 \cdot 2$
主成分の平均得点をプロットした。図 4、表 8、分布図（図6）よ り、6つに分類した緑地のそれぞれの特徵を都市機能・人口集積性 と交通施設開発度の成分からみていく。

○クラスター $1 \cdots$ 社会 I

このグループは、都市機能・人口集積性の要素である都市高速 IC、小中学校、高校、大学、公園、鉄道駅までの距離が遠く、人 口密度の平均値が最も低い值を示している。次に、交通施設開発度 の要素である九州道 IC、国道、鉄道駅までの距離をみると、九州 道 IC を除くと平均值に近い值を示している。したがって、社会 I は都市機能・人口集積性が最も低く、交通施設開発度は比較的高い 地域である。

○クラスター $2 \cdots$ 社会 II

このグループは、都市機能・人口集積性が高いことがわかる。 さらに交通施設開発度も高いことから、この緑地は市街地内または 市街地周辺の緑地である。したがって、社会 I は都市機能・人口集 穦性が最も高く、交通施設開発度も高い地域である。

○クラスター $3 \cdots$ 社会III

このグループは、都市機能・人口集積性は 2 番目に低いことがわ かる。交通施設開発度については、九州道 IC に近いが、国道や鉄 道駅までの距離は 2 番目に遠いことがわかる。したがって、社会而 恃都市機能・人口集積性、交通施設開発度ともに低い地域である。 ○クラスター $4 \cdots$ 社会 $\mathrm{IV}$

このグループは、最も交通施設開発度が低いことがわかる。都 市機能・人口集積性をみると平均値とほとんど変わらないが、人口 密度をみると、社会 I や社会而ほどではないが比較的低いことがわ かる。したがって、社会IVは都市機能・人口集積性が比較的低く、 交通施設開発度が最も低い地域である。

○クラスター $5 \cdots$ 社会 $\mathrm{V}$

このグループは、都市高速 IC までの距離は遠いものの、国道や 鉄道駅までの距離は 2 番目に近いことがわかる。都市機能・人口集 積性をみると、比較的低いことがわかる。したがって、社会Vは都 市機能・人口集積性怟低いが、交通施設開発度は最も高い地域であ る。

Oクラスター $6 \cdots$ 社会 $\mathrm{VI}$

このグループは、都市機能・人口集積性において社会 II の次に 高いことがわかる。交通施設開発度については全体の平均值とほぼ 変わりない。したがって、社会VIは都市機能・人口集積性が高く、 交通施設開発度も比較的高い地域である。

表 8. 各クラスターにおける社会的指標の平均值・メッシュ数およびクラスター分析結果による各主成分の平均得点

\begin{tabular}{|c|c|c|c|c|c|c|c|c|c|c|c|c|c|}
\hline & \multirow[t]{2}{*}{ 九州道IC } & \multirow[t]{2}{*}{ 都市高速IC } & \multirow[t]{2}{*}{ 国道 } & \multirow[t]{2}{*}{ 小中学校 } & \multirow[t]{2}{*}{ 高校 } & \multirow[t]{2}{*}{ 大学 } & \multirow[t]{2}{*}{ 公園 } & \multirow[t]{2}{*}{ 鉄道歌 } & \multirow[t]{2}{*}{ 人口密度 } & \multirow[t]{2}{*}{ メッシュ数 } & \multicolumn{2}{|c|}{$\begin{array}{c}\text { 主成分平均得点 } \\
\text { (クラスター分析結果) }\end{array}$} \\
\hline & & & & & & & & & & & & 第1主成分 & 第2主成分 \\
\hline $35 \pi y-1$ & 平均值 & $7,052.9$ & $11,072.5$ & $2,063.9$ & $3,387.4$ & $8,892.5$ & $8,792.7$ & $8,950.1$ & 2928.0 & 43.7 & \multirow{2}{*}{325} & \multirow{2}{*}{2.492} & \multirow{2}{*}{-0.665} \\
\hline (社会 I) & 順位 & (5) & (6) & $(3)$ & (6) & (6) & $(6)$ & $(6)$ & (3) & (6) & & & \\
\hline クラスタ -2 & 平均值 & $5,464.3$ & $2,455.4$ & 985.7 & 662.6 & $1,488.7$ & $3,017.2$ & $1,188.9$ & $1,518.5$ & $3,377.6$ & \multirow{2}{*}{1,336} & \multirow{2}{*}{-0.852} & \multirow{2}{*}{-0.739} \\
\hline (社会 II) & 順位 & $(3)$ & (1) & (1) & (1) & (1) & $(1)$ & $(1)$ & $(1)$ & $(1)$ & & & \\
\hline クรスタ-3 & 平均值 & $4,921.5$ & $6,366.8$ & $3,693.8$ & $2,585.0$ & $6,207.0$ & $6,697.2$ & $5,304.7$ & $4,661.3$ & 64.5 & \multirow{2}{*}{609} & \multirow{2}{*}{1.001} & \multirow{2}{*}{0.732} \\
\hline (社会 III) & 順位 & $(2)$ & (5) & (5) & $(5)$ & $(5)$ & (5) & (5) & (5) & (5) & & & \\
\hline クラスタ-4 & 平均值 & $11,007.8$ & $6,148.4$ & $4,453.8$ & $1,367.9$ & $4,457.5$ & $4,816.3$ & $2,882.2$ & $5,191.4$ & 324.2 & \multirow{2}{*}{492} & \multirow{2}{*}{-0.101} & \multirow{2}{*}{1.801} \\
\hline (社会IV) & 順位 & $(6)$ & (3) & $(6)$ & (4) & (3) & (3) & (3) & (6) & (4) & & & \\
\hline クラスタ-5 & 平均值 & $3,134.2$ & $6,222.0$ & $1,226.9$ & 984.5 & $4,955.5$ & $6,036.9$ & $3,681.1$ & $1,936.7$ & 555.4 & \multirow{2}{*}{720} & \multirow{2}{*}{0.600} & \multirow{2}{*}{-1.020} \\
\hline (社会V) & 順位 & (1) & (4) & (2) & (2) & (4) & (4) & (4) & (2) & (2) & & & \\
\hline $35 x 3-6$ & 平均值 & $6,101.1$ & $3,405.7$ & $2,545.6$ & $1,256.1$ & $2,492.4$ & $3,402.9$ & $2,265.1$ & $3,174.0$ & 468.8 & \multirow{2}{*}{1,434} & \multirow{2}{*}{-0.463} & \multirow{2}{*}{0.422} \\
\hline (社会VI) & 順位 & (4) & (2) & $(4)$ & (3) & $(2)$ & (2) & $(2)$ & (4) & (3) & & & \\
\hline 平均 & 值 & $5,901.4$ & $4,708.1$ & $2,229.9$ & $1,371.7$ & $3,660.3$ & $4,589.7$ & $3,060.3$ & $2,912.8$ & $1,179.3$ & & & \\
\hline
\end{tabular}

※峃位は。人口密度が人 $/ \mathrm{km}^{2}$ 。その他は $\mathrm{m}$ 
4-3. 用途地域指標による分類と緑地分布特性

用途地域内に存在する緑地の分類を行う。用途地域を住居系、 商業系、工業系の3つに大分類し、それに市街化調整区域を加え、 4 分類とした（表 9 ）。分布図を図 7 に示す。

商業系、工業系地域に存在する緑地は住居系地域、市街化調整 区域と比べても極めて少ない。これは、商業系、工業系地域が中心 市街地内もしくは中心市街地に隣接しているためである。住居系地 域は市街地に隣接していると同時に、山間部と隣接しているため、 その地域内には緑地がある程度存在している。市街化調整区域は山 間部とその周辺に存在しているため緑地がかなり多く存在する。

\section{表 9. 分類結果（用途地域指標）}

\begin{tabular}{|c|c|c|c|c|c|c|c|}
\hline \multirow[t]{2}{*}{ 分類 } & \multirow[t]{2}{*}{ 用途地城 } & \multirow{2}{*}{\multicolumn{2}{|c|}{ メッシンン数 }} & \multirow{2}{*}{\multicolumn{2}{|c|}{ 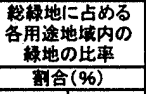 }} & \multirow{2}{*}{\multicolumn{2}{|c|}{ 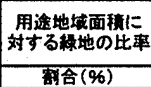 }} \\
\hline & & & & & & & \\
\hline \multirow{7}{*}{ 住居系地找 } & 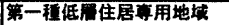 & 488 & & 9.93 & \multirow{6}{*}{2.78} & 69.22 & \\
\hline & 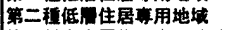 & 28 & & 0.57 & & 49.12 & \\
\hline & 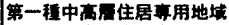 & 240 & & 4.88 & & 43.64 & \\
\hline & 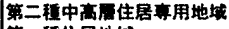 & 0 & 1,120 & 0.00 & & 0.00 & 50.72 \\
\hline & 第一程住居地域 & 354 & & 7.20 & & 41.50 & \\
\hline & 第二程住居地域 & 10 & & 0.20 & & 27.03 & \\
\hline & 嚾住居地域 & 0 & & 0.00 & & 0.00 & \\
\hline \multirow{2}{*}{ 商集系地找 } & 近嚾商等地城 & 6 & 19 & 0.12 & 0.39 & 6.45 & 6.48 \\
\hline & 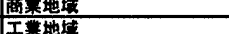 & $\frac{13}{6}$ & & 0.26 & & 6.50 & \\
\hline \multirow{2}{*}{ 工莱系地线 } & & $\begin{array}{r}0 \\
46\end{array}$ & 121 & $\begin{array}{l}0.12 \\
0.94\end{array}$ & \multirow{2}{*}{2.46} & $\begin{array}{ll}6.98 \\
1513\end{array}$ & 1156 \\
\hline & 工焦算用地域 & $\begin{array}{l}40 \\
69 \\
\end{array}$ & & 1.40 & & 10.50 & 11.00 \\
\hline \multirow{2}{*}{\multicolumn{2}{|c|}{ 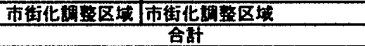 }} & & 3,656 & \multirow{2}{*}{\multicolumn{2}{|c|}{$\frac{74.37}{100.00}$}} & \multirow{2}{*}{\multicolumn{2}{|c|}{89.06}} \\
\hline & & $(* 1)$ & 4,916 & & & & \\
\hline
\end{tabular}

(*1):1997 年の緑地の $250 \mathrm{~m}$ メッシュ数

\section{4-4．被覆指標による分類と緑地分布特性}

ここでは被覆指標を用いて分類を行う。指標は1987 年から 1997 年にかけて、緑地が市街地へ変化した量（250m メッシュ数）とす

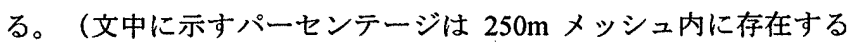
$50 \mathrm{~m}$ メッシュの数の割合である) 分類の方法は、まず対象となるメ ッシュについて 1987 年に市街地を $80 \%$ 以上含むメッシュを市街化 I として設定する。次に 1987 年に $60 \%$ 以上 $80 \%$ 未満が市街地であ るメッシュで、1987 年から 1997 年の 10 年間に市街地へ变化した 割合が $20 \%$ 以上のものを市街化 II 、20\%未満のものを市街化III 設定する。以下同様にして、表 10 のように市街化IVから市街化IX に分類した。なお、1987 年から 1997 年にかけて変化がみられなか ったメッシュを市街化Xとして設定した。表 10 に分類結果、図 8 に分布図を示す。

表 10 . 分類結果 (被覆指標)

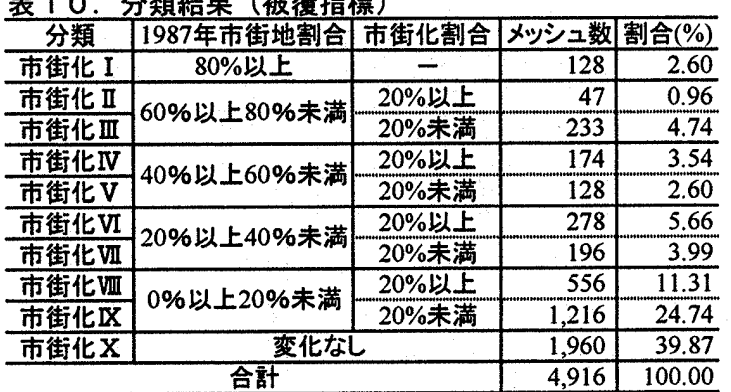

まず市街化 II 、市街化且の 10 年間の緑地が市街地へ変化した割 合を示す市街化割合についてみると、20\%以上の変化があった市 街化 I のメッシュ数に対して、20\%未満の変化量があった市街化 IIIのメッシュ数がはるかに上回っている。これはメッシュ内に既に 市街地が多く存在していたため、市街地一変化する緑地が少なかっ たものと考えられる。次に市街化IV、市街化Vについては、市街化

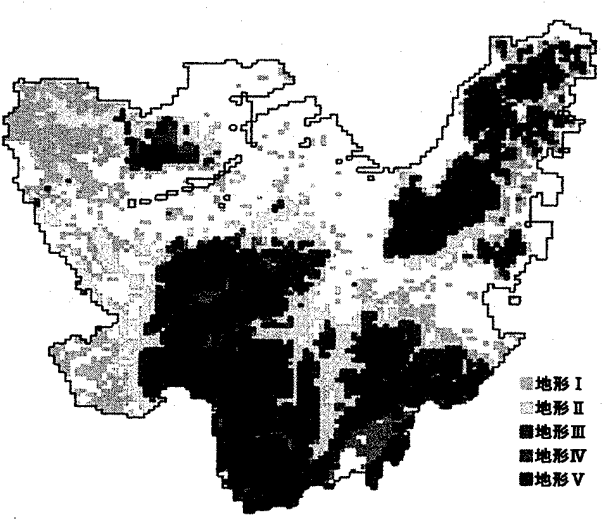

图 5. 地理的指樌による分類結果

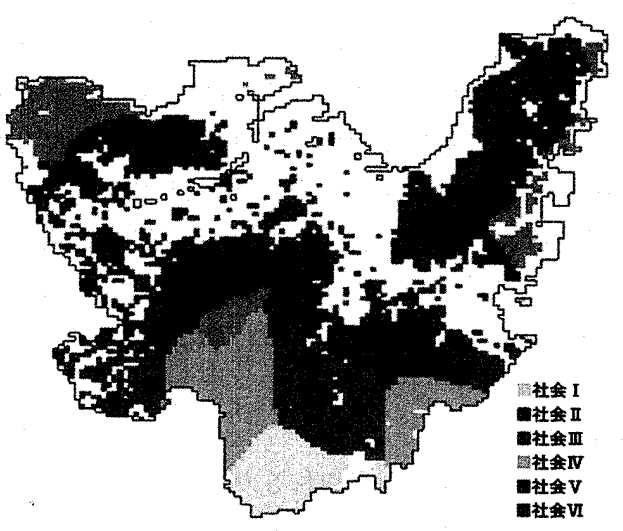

图 6. 社会的指灀による分類結果

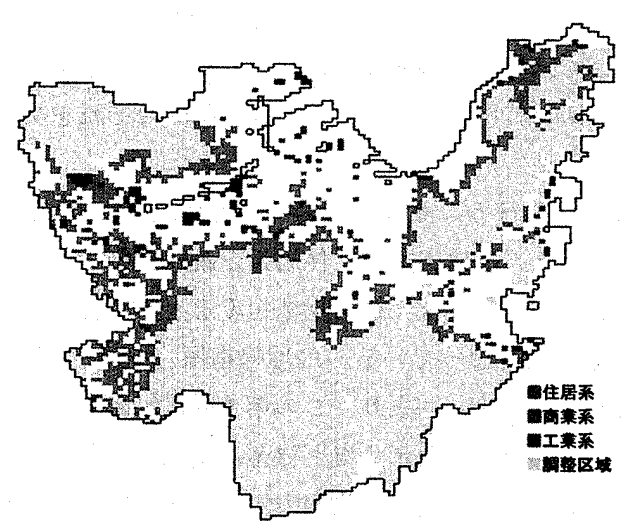

図 7.用途地域指相による分類結果

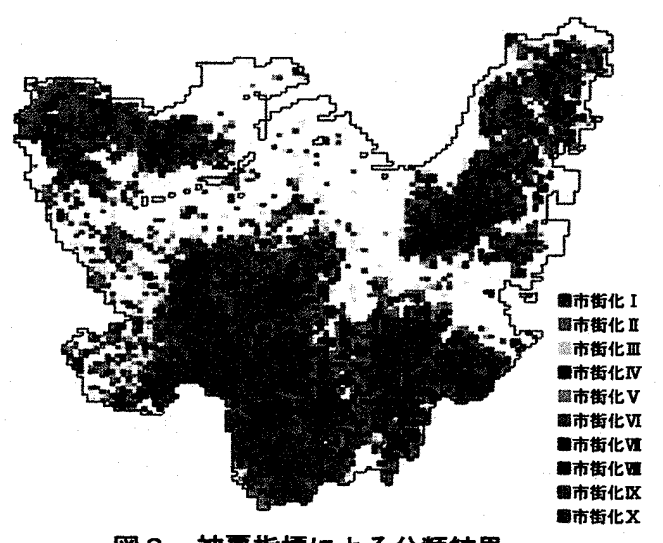

図 8. 被夏指灀による分類結果 
割合が $20 \%$ 以上のメッシュ数が $20 \%$ 未満のメッシュ数を上回って いる。1987 年にある程度市街化が進行していたこれらの地域は、 10 年間における緑地の減少傾向が強いことがわかる。これは市街 地近傍の緑地が市街化されやすいという傾向があることを示してい る。また、市街化VI、市街化VIIの地域は市街化IV、Vと同様の傾向 がみられる。市街化㚼と市街化Xにについては、メッシュ数をみれば 市街化 II 、III 同じ傾向がみられるが、その内容は異なる。既に市 街地が多く存在していた市街化II、IIIの地域に対して、市街化VII IXの地域はもともと市街地が少なく、市街化の進行のスピードが高 くなっていないということである。

\section{4-5. 数量化正類分析・クラスター分析による類型化}

設定した環境要因をもとに数量化而類分析、クラスター分析を 行い、緑地分布メッシュの類型化を行う。ここでは、緑地自体の集 塊度を示す C 値 ${ }^{(5)}$ と植生の活性度を示す NDVI の緑地環境指標を加 えた。ここでこれらの緑地環境指標を加えるのは、類型化を行う上 で、他の環境要因のみでは表すことのできない潜在的な、すなわち 緑の規模やその植生といった緑地自体の指標が必要であると考えら れるためである。この緑地環境指標を加えることで、緑地分布メッ シュの更に厳密な類型化が可能になると考えられる。

\section{（数量化 III類分析）}

まず、数量化亚類分析から得られるカテゴリースコアから軸の解 釈を行っていくが、軸の相関係数が 0.5 以上の軸を対象とした。そ の場合、第 1 軸から第 3 軸までの 3 つの軸が対象となったが第 3 軸 については有効な結果が得られなかったので除外し、第 1 軸、第 2 軸を対象にして、緑地の特性を把握した。表 11 は第 1 軸、第 2 軸 のカテゴリースコアを記したものであり、図 9 はそれをプロットし たものである。

第 1 軸の解釈を行う。まず用途地域指標からみると商業系が高 い值を示している。次に工業系、住居系と続き市街化調整区域が一 番低い值になっている。次に被覆指標をみると市街化 I から市街化 $\mathrm{X}$ と順番に值が低くなっている。地理的指標、緑地 $\mathrm{C}$ 值について も同様のことがいえる。つまり、この第 1 軸は緑量を表す軸で、カ テゴリースコアが負の值を示すほど緑量が増えること表す。

第 2 軸の解釈を行う。まず被覆指標、地理的指標についてみる と、この軸で特徴的なのは、市街化 I と地形 Vである。緑量ではこ の 2 つは第 1 軸で示すように対照的な特徴を持っており、市街化 I は緑量が少なく地形 Vでは緑量が多い。しかし、第 2 軸においては この $2 つ は$ 似通った特徵を持っている。つまり、この軸は緑地に直 接的に関わった特徴を持つ軸であるとは考えられない。そこで軸を 市街地形成に着目しながら解釈していく。被覆指標では、市街地を 多く含むメッシュである市街化 I と II、用途地域指標では、市街地 が密集している商業系と工業系、緑地環境指標では、緑地の集塊度 が低い緑地 C 值 I と II 、植生の活性度が低い NDVII と II のカテゴ リースコアが高くなっている。これらのカテゴリーはいずれも、市 街地の開発進行の度合いを表すものと考えられる。したがって、こ の第 2 軸は開発速度を表す軸で、カテゴリースコアが負の值を示す ほど開発速度が速くなることを表す。

\begin{tabular}{|c|c|c|c|c|c|c|c|c|c|}
\hline \multirow{3}{*}{ 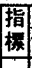 } & & \multirow{2}{*}{ メッシュ数 } & \multicolumn{2}{|c|}{ カテテコリースコア } & \multirow{2}{*}{$\begin{array}{l}\text { 指 } \\
\text { 楼 }\end{array}$} & \multirow{2}{*}{ カテゴリー } & \multirow[b]{2}{*}{ メッシュ数 } & \multicolumn{2}{|c|}{ カテゴリースコア } \\
\hline & & & 第轴 & 第2 輔 & & & & 第1軸 & 第2軸 \\
\hline & 布街化 I & 128 & 2.53423 & 3.74054 & & 社会 I & 325 & -1.33213 & 1.37008 \\
\hline & 市街化 II & 47 & 2.52848 & 3.23533 & & 社会 II & 1336 & 1.33344 & 0.54768 \\
\hline & 市街化而| & 233 & 2.14983 & 1.47948 & $\mid$ & 社会 III & 609 & -1.27533 & 1.0847 \\
\hline & 市街化IV & 174 & 1.94158 & 1.38532 & 的 & 社会 IN & 492 & 0.40143 & -1.81047 \\
\hline 被 & 市街化V & 128 & 1.67833 & -0.47726 & & 社会V & 720 & -0.05219 & 0.37521 \\
\hline a & 市街化 vI & 278 & 1.39372 & 0.19996 & & 社会VI & 1434 & -0.5103 & -0.84865 \\
\hline & 市街化林 & 196 & 0.97677 & -1.62559 & & 楾地C值 I & 266 & 2.24888 & 2.73276 \\
\hline & |市街化Vu| & 556 & 0.44961 & -1.00207 & & 粶地C值 II & 205 & 2.19786 & 2.16377 \\
\hline & 市街化 IX & 1216 & -0.06974 & -1.46448 & & 緑地C值 III & 157 & 1.6793 & 0.97082 \\
\hline & 市街化 X & 1960 & -1.1433 & 0.73748 & & 緑地C值IV & 156 & 1.53484 & 0.2222 \\
\hline & 地形 I & $\overline{572}$ & 1.67339 & 0.58967 & & 緑地C值 V & 216 & 1.21155 & -0.76583 \\
\hline 地 & 地形 II & 843 & 1.33534 & -0.06909 & 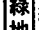 & 粶地C俌VI & 396 & 0.8977 & -1.67334 \\
\hline 形 & 地形 III & 1005 & 0.51115 & -1.75268 & 地 & 粶地C值 VI & 871 & 0.39222 & -2.13221 \\
\hline 的 & 地形 $\mathbf{N}$ & 1242 & -0.89654 & 0.11101 & 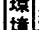 & 程地C值训 & 2649 & -0.94777 & 0.50119 \\
\hline & 地形 V & 1254 & -1.18268 & 1.07219 & & NDVII & 153 & -0.79603 & 1.45748 \\
\hline 用 & 住居系 & 1120 & 1.7117 & 0.37538 & & NDVI II & 766 & -0.38925 & 1.20639 \\
\hline |途 & 商菜系 & 19 & 2.79087 & 5.91611 & & NDVIII & 3093 & 0.26549 & -0.28431 \\
\hline 地 & 工羓系 & 121 & 2.29235 & 2.2695 & & NDVIIV & 903 & -0.44604 & -0.29731 \\
\hline 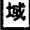 & 睭整区域 & 3656 & -0.61474 & -0.22085 & & NDVIV & & 1.58364 & 0.74845 \\
\hline
\end{tabular}

※緑地 C 值、NDVI のカテゴリーについては補注(7)参照。

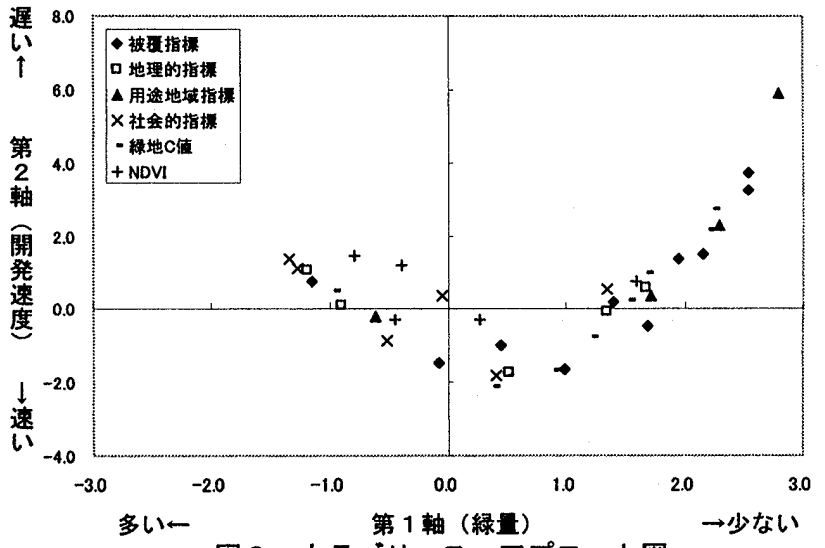

図 9.カテゴリースコアプロット図

（クラスター分析）

数量化而類分析ではカテゴリーの第 1 軸が緑量、第 2 軸が開発速 度を表しているとした。次に数量化而類分析の結果をもとにクラス ター分析（最短距離法）を行う。まずクラスター番号 1〜4をそれ ぞれ類型 I 、類型II、類型III、類型IV とする。表 12 に各クラスタ 一のメッシュ数とそれぞれの割合を示す。図 10 第 1 軸（横軸）

は緑量、第 2 軸（縦軸）は開発速度を示している。また、図 11 に この類型結果の分布図を示す。これらから、各類型の解釈を行う。

\begin{tabular}{|c|c|c|}
\hline 分類 & メッシュ数 & 割合(\%) \\
\hline クラスター1(類型 I ) & 1,273 & 25.90 \\
\hline クラスター2(類型 II) & 2,351 & 47.82 \\
\hline クラスター3(類型正) & 498 & 10.13 \\
\hline クラスター4(類型IV) & 794 & 16.15 \\
\hline 合計 & 4,916 & 100.00 \\
\hline
\end{tabular}

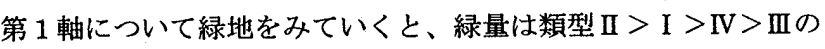
順番で多いことがわかる。図 11 からもそれぞれ、類型 I は山地に 近い地域に存在する緑地、類型 II は山地の緑地、類型而は緑量から みて市街地内もしくは市街地周辺部の緑地、類型IVは類型 I に隣接 している市街地に近い地域の緑地と考えられる。次に第 2 軸の開発 速度をみていく。開発速度は類型 I $>\mathrm{IV} \leftrightharpoons$ II $>\mathrm{III}$ の順番で速い。こ の開発速度は、市街地に近い地域の緑地と山地の緑地では、ほぼ同

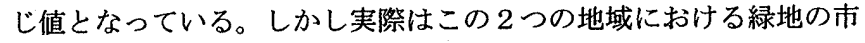
街化の速度は対照的である。そこでこの 2 つを区別する必要がある。 緑量と開発速度の 2 点から、これら 4 つに分類された緑地を、類型 
I は緑量が比較的多く市街化が進行している緑地、類型 II は山地の 緑量の多い市街化が進行しにくい緑地、類型而は緑量の少ない市街 地内の緑地、類型IVは緑量が少なく、ある程度市街化が進行した緑 地とした。これを表 13 にまとめる。

\section{5. 類型結果の検証}

これまでに得られた結果を検証する意味で、類型結果と緑地分布、 緑地環境指標である NDVI、集塊度（C 值）との関連をみることに する。表 14 から表 16 に類型結果とそれらとの関連を示す。

表 14 によると、250m メッシュ内に含まれる緑地の $50 \mathrm{~m}$ メシ 二数の平均值が、類型 II > I > IV > III となっている。最大值でも類 型而が最も小さい值をとっており、類型結果が妥当であることがわ

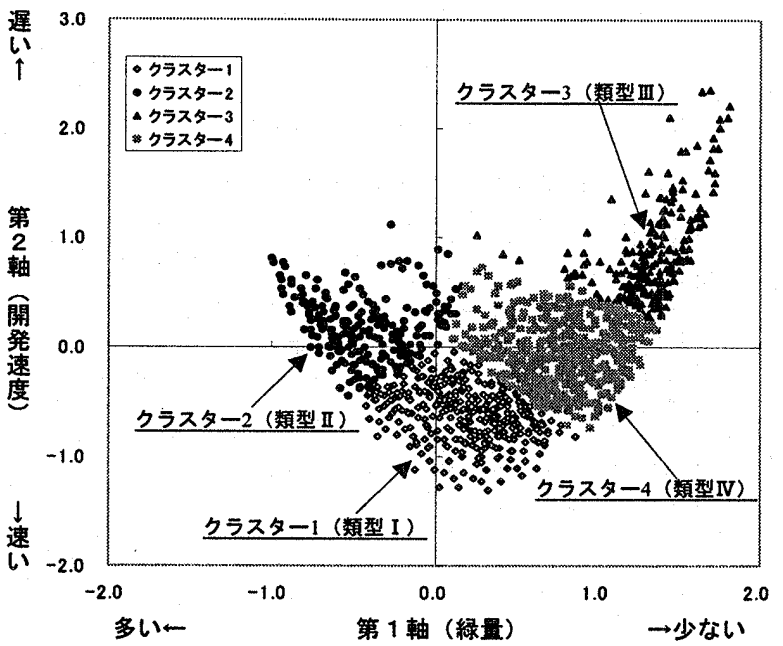

図10. サンプルスコアプロット図

表 13 . 緑地分布メッシュの類型と特性

\begin{tabular}{|c|c|}
\hline 類型 & 特栍 \\
\hline 1 & 高街花が進衍している緑地 \\
\hline 類型 I & 山間部で緑䵤が多く、市街化が進䘕にくい緑地 \\
\hline 類型而 & 緑曋が少ない，市街地内の緑地 \\
\hline
\end{tabular}

かる。表 15 によると、NDVI の平均值は、類型 I $>$ IV $>$ II $>$ III と なっている。類型 II 、III、IVは大きな差はみられないが、類型IIIが 最も大きな值をとっている。表 16 によると、集塊度の平均値は表 14 同様に、類型 II > I > IV > III となっている。最大值では類型 II が最も高い値をとっており、市街地内の緑地が分類されている類型 IIIが最も低い値となっている。この類型結果も妥当といえる。

\section{6. 総括}

$6-1$. 結論

本論では、まず、環境要因別に緑地の分布傾向と特性を把握し、 分類を行った。その結果を用いて、数量化亚類分析とクラスター分 析により、緑地分布メッシュの類型化を行い、緑地分布メッシュを その緑量、開発速度から 4つに類型化（表 13 ）することができた。 この類型結果から次のように緑地環境の保全・活用の方向性を(1)か ら(3のように示すことができると考えられる。

(1) 類型 Iの緑地に関しては、市街化された地域と緑地が多く 分布している地域の間に分布しており、緑地環境の保全や 活用の方向性だけではなく、良好な緑地環境保全のための 市街化のコントロールや誘導策を講じる必要がある。

(2) 類型IIに関しては、自然度が高く、山岳部に大規模に緑地 が分布しており、類型 I との関係も考慮しながら、保全の 方向性を示す必要がある地域である。

(3) 市街地内で緑量が少ない類型而や緑量が少なく市街化があ る程度進行した類型IVの地域に関しては、緑量が既に少な いという点から、緑地環境の維持や残存緑地の活用の方向 性を明らかする必要がある地域・地点である。

\section{6-2. 今後の課題}

本論で行った緑地分布メッシュの類型化は、社会的な諸情報と緑 地自体の性質・特性を組み込んだ緑地分布状況の把握である。都市 市全域を対象として研究を進めたために、山地などの大規模に密集 する緑地恃開発圧力をほとんど受けないにもかかわらず、類型化の 対象となった。研究の主眼点でもある都市内の、特に都心部や既成

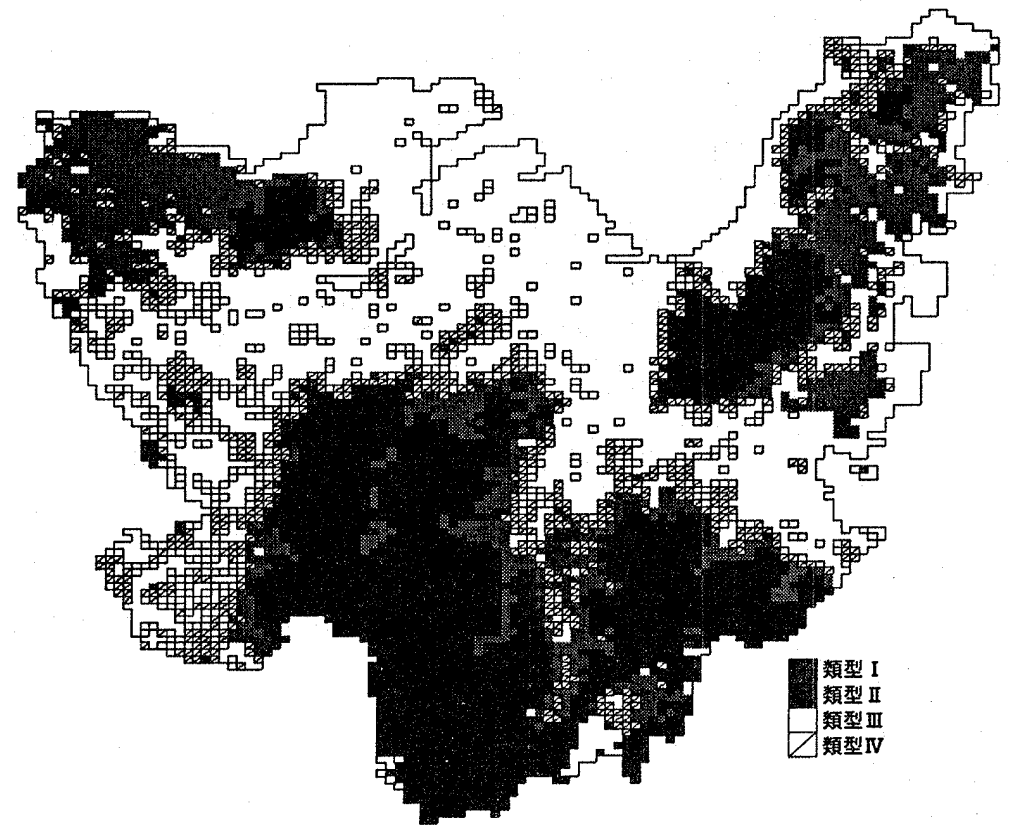

図 11 . 緑地分布メッシュの類型結果分布图
表 14. 分類結果と緑地（土地被覆）との比較

\begin{tabular}{|c|c|c|c|c|c|}
\hline & & & 緑地 & $0 m x$ & 7) \\
\hline 類型 & メッシュ数 & 割合(\%) & & & 安大伍 \\
\hline 類型 I & 1,273 & 25.90 & 14.35 & 4 & 25 \\
\hline 類型II & & & 22.67 & 1 & 25 \\
\hline 頙型而 & 498 & 0.13 & 1.97 & 1 & 11 \\
\hline 類型IV & 4 & & 6.91 & & 25 \\
\hline 合該 & 216 & 00. & 15.88 & 1 & 25 \\
\hline 15 & & & & & \\
\hline 分類 & メッシユ数 & 割合(\%) & $\frac{\text { NDVI }}{\text { N均徝 }}$ & 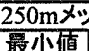 & 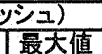 \\
\hline 兹 & 73 & 25.90 & 133.59 & 97 & 151 \\
\hline 賛 & 2,351 & 47 & 128.13 & 77 & 15 \\
\hline & 45 & 10 & & 66 & 152 \\
\hline 型N & 79 & 16. & 129.38 & 80 & 16 \\
\hline & 4,91 & 0. & 129.70 & 66 & 16 \\
\hline
\end{tabular}

表 16. 分類結果と集塊度 (C 值) との比較

\begin{tabular}{|c|c|c|c|c|c|}
\hline & & & \multicolumn{3}{|c|}{ C值 $(250 \mathrm{~m} \times$ ソシ $)$} \\
\hline 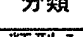 & ンツン ב & 部口( & & \begin{tabular}{|l} 
最小值 \\
\end{tabular} & \begin{tabular}{|l|} 
最大值 \\
\end{tabular} \\
\hline 類型 & 1,273 & 25.90 & 7.36 & 3.00 & 8.90 \\
\hline 類型 II & 2,351 & 47.82 & 8.50 & 1.00 & 9.00 \\
\hline 類型而 & 498 & 10.13 & 2.34 & 1.00 & 8.46 \\
\hline 類型 $\bar{N}$ & 794 & 16.15 & 5.77 & 1.00 & 8.74 \\
\hline 合計 & 4,916 & 100.00 & 7.14 & 1.00 & 9.00 \\
\hline
\end{tabular}

※表 14 16内のメッシュ数は $250 \mathrm{~m}$ メッシュ数を表す。 
市街地内での緑地の分布状況やその特性を更に詳細に把握すること も重要な研究の対象となってくる。

今後の課題として、今回の解析結果や手法を分析対象の都心部 等の既成市街地に適用し、市街地内に存在する緑地を対象としたミ クロ的な類型化を行うことがあげられる。これにより、市街地内の 緑地環境評価を、さらに詳細に示すことが可能になると考えられる。

\section{【謝辞】}

本論は文部省科学研究補助費（基盤研究 B、課題番号 11555159）の一部をなすものである。また、本論は本学博士前期 課程修了生の三宅隆喜氏（現構造計画研究所）の協力を得て取りま とめたものであり、感謝の意を表する。最後に、匿名査読者より極 めて貴重なご意見を頂いた。感謝の意を表する。

【補注】

（1） ランドサットTMデータはリモートセンシング技術センター等の供給 センターでデータの入手が可能である。ランドサットTMデータはア メリカ合衆国政府に所有権がある。使用したランドサット TM ゙ータ の概要は以下のとおりである。ランドサット TM データの加工にはリ モートセンシング解析ソフトである、PCI Remote Sensing Corp.製の PCIを使用して行った。

観測日：1987年 12 月 4 日, 1997月 2 月 4 日

パスーロウ：113-37 (フトシータ），113-36（サブシーン）を合成

作成方法：教師付き分類

分類手法：最尤法

グランドトウルースデータ：1/25,000 地形図

作成した土地被覆分類は次のカテゴリ一を持つ。人工構造物を示す市 街地、緑地、生産系緑地、裸地、水域の 5 カテゴリーである。研究で 使用寸るデー夕は実精度が約 $28.5 \mathrm{~m}$ 四方のデー夕を $50 \mathrm{~m}$ 四方へと変 換している。また、本研究で使用した NDVI（正規化植生指標=

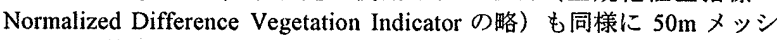

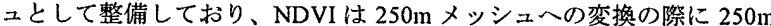
メッシュ内（25 個の $50 \mathrm{~m}$ メッシュ）の平均值を使用した。なお、 NDVI は高い值を示すほど植生が高く、逆に低い值を示すと植生が低 いことを示し、本論では 0 から 200 の数值によって表している。なお、 NDVI の算出式は以下によった。

$$
N D V I=\frac{\text { Band } 4-\text { Band } 3}{\text { Band } 4+\text { Band } 3}
$$

土地被覆についての分類方法であるが、あらかじめ緑地（市街地等も 同様)である複数の地点をグランドトゥルースデータにより指定して おき（教師付き）、この指定した地点の分光反射特性に近い特性を持 つメッシュ（ピクセル）を緑地として分類していく手法（最尤法）で ある。これにより前揭 5 つの土地被覆を分類する。また、特に緑地の 変化についてであるが、2 時点間のそれぞれの分類結果を比較し、 1987 年では緑地として判定されていたが、1997 年では緑地として判 定されていない地点を「緑地が減少した地点」としている。

（2）数值地図 2500 (空間データ基盤）は楛造化されだデータで、1/2500 の都市計画基本図を原資料として作成されている。また、空間データ 基盤のほかに人口のデータを用いている。人口は、平成 7 年国勢調査 （福岡県）を用いた。なお、これらのデータのメッシュデータ化には、 空間情報システムである Cadcorp 製の SIS ver5.2 を用いて行った。

（3）数值地図 $50 \mathrm{~m}$ メッシュ（標高）は $1 / 25,000$ 地形図を基図として、等高 線から計算によってメッシュの中心点の標高值が収められた数值標高 モデル (DEM) データである。地形図 (2 次メッシュ) を経度方向及 び緯度方向に 200 等分し、実距離が約 $50 \mathrm{~m}$ の精度を持つメッシュデー タとして整理されている。

(4) 用途地域デー夕は北九州市役所からご提供いただいたものである。デ フォルトでは ArcViewのフアイルフォーマットである Shp 形式として 整備されている。本データのメッシュデータ化は補注(2)と同様に行っ た。

（5）集塊度指標（C 值）の測定には参考文献 10）の手法を用いた。集塊度 とはある土地利用のまとまり具合（分散して分布しているのか、ある いはまとまって分布しているのか) を定量的に示すものである。

(6) 文献 11)によると、 $0^{\circ} \sim 3^{\circ}$ が平坦地であり開発適地、 $3^{\circ} \sim 8^{\circ}$ が緩 斜地で宅地として安全であり、斜路の限界、 $8^{\circ}$ を超えると住宅建設 一般の限界であり、1 $5^{\circ}$ を超えると防災対策必要で住宅地として適さ ないことが明記されている。また文献 12)によると、平均斜度約 $8^{\circ}$

（台地～傾斜地）を超えると、整地費（ha 当り）が高くなっているこ とが示されている。また、平均斜度 $14^{\circ}$ (傾斜地) を超えると、整地 費（ha 当り）は更に上昇し、技術面のみからではなく、コスト面から
の開発適地選定の重要性も述べられている。これを参考に傾斜度の分 類を 4 つに定めた。

(7) a) 集塊度を示す C 值のカテゴリーは以下のとおりである。C 值は 0 か ら9の值をとり、大きいほど集塊度が高く、小さいほど集塊度が低く なる。今回使用した C 值は、測定範囲を $1,500 \mathrm{~m}$ として算出したもの である。

C 值 I : 2 末満

C 值 II : 2 以上 3 未満

C 值III : 3 以上 4 未満

C 值IV : 4 以上 5 未満

$\mathrm{C}$ 值 V: 5 以上 6 末満

C 值VI: 6 以上 7 未満

C 值VII : 7 以上 8 未満

$\mathrm{C}$ 值VIII : 8 以上

b) NDVI のカデ゙リーは以下のとおりである。（算出方法は補注(1)） NDVI I : 100 末満

NDVI II：100以上 110 未满

NDVIIII : 110 以上 120 未満

NDVIIV : 120 以上 130 未満

NDVIV : 130 以上

【参考文献】

1)この研究に関しては多くの報告があるが、以下のような代表的な例があげ られる。

小出治 : 土地利用混合度の適用並びにその検定，日本都市計画学会 学術研究論文集, 第 12 号, pp.79-84, 1977.11

玉玉川英則：土地利用の秩序性の数理的表現に関する考察，日本都市 計画学会学術研究論文集, 第 17 号, pp.73-78, 1982.11

文泰憲, 萩島哲, 大貝彰 : 土地利用混合度指標に関する研究, 日本都 市計画学会学術研究論文集, 第 26 号,pp.505-510, 1986.11

恒川篤史, 李東根他: 土地利用混在の定量化手法, 環境情報科学, 第 20 巻第 2 号, pp115-120, 1991

吉川徹 : メッシュデータに立脚した土地利用の集塊性の把握手法に つて, 日本建築学会計画系論文集, No.495, pp.147-154, 1997.5

吉川徹 : メッシュデータに立脚した同種・異種土地利用の集塊性の 把握手法, 日本建築学会計画系論文集, No.520, pp.227-232, 1999.6

山崎正晴, 伊藤邦明他：塊状植生被覆を用いた都市植生の評価手法 に関する研究, 日本建築学会大会学術講演梗概集, F-1 分冊, pp.655$656,1998.9$

2) 文泰憲, 萩島哲, 大貝彰, 岩尾襄 : メッシュデータによる都市内の緑地保全 のための評価手法に関する研究，日本都市計画学会学術研究論文集，第 27 号, pp.547 552, 1997.11

3)宮崎隆昌, 中澤公伯 : 東京湾沿岸地域における土地利用の総体的把握と分 析システムの開発一大都市沿岸域における環境評価方法に関する研究，日 本建築学会技術報告集, 第 9 号, pp.213 218, 1999.12

4) 大林成行, 小島尚人：階層化意思決定法を導入した土地分級評価アルゴリ ズムの構築, 土木学会論文集, No.546/VI-32, pp169〜179, 1996.9

5)岩見良太郎, 川上秀光, 呂斌: ポテンシャル概念にもとづく緑地環境評価と 緑地価値の計測, 日本都市計画学会学術研究論文集, 第 22 号, pp.13 18, 1987.11

6) 青木陽二：緑地環境水準の評価指標の算定方法に関する研究, 日本都市計 画学会学術研究論文集, 第 17 号, pp.481 486, 1982.11

7)坂口利裕, 額田順二, 阪本一郎, 高辻秀興 : ポイントサンプリングデータを 用いた緑地分布と変化の把握, 日本都市計画学会学術研究論文集, 第 28 号, pp.385 390, 1993.11

8)金子忠一, 䕒茂寿太郎 : 都市における残存斜面緑地の特性についての調査 研究一特に、川崎市における調査をふまえて一, 日本都市計画学会学術研究 論文集,第 20 号, pp.367 372,1985.11

9)田代順孝, 杉本亮一: オープンスペース計画から見た緑被地の残存規模特 性, 日本都市計画学会学術研究論文集, 第 24 号, pp.115 120,1989.11

10）小林祐司，佐藤誠治，有馬隆文，姫野由香：ラシドサット TM データを利 用した緑地分布傾向の把握手法に関する研究, 日本都市計画学会学術研 究論文集, 第 35 号, pp.1009 1014, 2000.11

11）水口俊典：土地利用計画とまちづくり 規制・誘道から計画協議人, 学芸 出版社, pp.44, 1997

12）宅地開発便覽編集委員会: 宅地開発便臨，鹿島研究所出版会, pp.74-75, 1974

（2001年 9 月 7 日原稿受理，2001年12月26日採用決定） 